\title{
Carcass characteristics, non-carcass components and meat quality of Nellore cattle in a feedlot and fed with different corn hybrids ${ }^{1}$
}

\section{Características de carcaça, de componentes não carcaça e qualidade da carne de bovinos nelore em confinamento e alimentados com diferentes híbridos de milho}

\author{
Bruna Bonini Sestari²; Ivone Yurika Mizubuti ${ }^{3,1 *}$; \\ Edson Luis de Azambuja Ribeiro ${ }^{3,1}$; Marco Aurélio Alves de Freitas Barbosa ${ }^{3}$; \\ Elzânia Sales Pereira ${ }^{4,1}$; Andréa Pereira Pinto ${ }^{4}$; Gianne Evans Cunha ${ }^{2}$; \\ Rodrigo da Costa Gomes ${ }^{5}$; Fernando Luiz Massaro Junior ${ }^{2}$; Carla Prado Rosolem ${ }^{6}$
}

\begin{abstract}
The objective of this study was to evaluate carcass characteristics, non-carcass components and meat quality of Nellore cattle in feedlot and fed with different corn hybrids (flint, semi-flint and semi-dent) in the diet. Twenty-seven animals averaging $350 \pm 24 \mathrm{~kg}$ of body weight and 24 months of age were used. The animals were distributed in a completely randomized design with three treatments $(\mathrm{T})$, where, T1- diet with flint corn (TDFC), T2- diet with semi-flint corn (TDSFC) and T3- diet with semi-dent corn (TDSDC), with 9 replicates per treatment. The animals were fed ad libitum twice daily (at 8:00 am and $4: 00 \mathrm{pm}$ ) with isocaloric and isonitrogenous diet, with $30 \%$ of sugar cane bagasse and $70 \%$ concentrate (88\% maize, $8 \%$ soybean meal, $3 \%$ mineral and vitamin supplement and $1 \%$ urea) for 95 days (14 days of adaptation and 3 experimental periods of 27 days each). The animals were weighed at the beginning of the experiment and after each period of 27 days, always in a fasting period of 16 hours. At the end of the experiment, the animals were slaughtered in commercial slaughterhouse, measuring non-carcass components (weight of blood, feet, hide, head, tail, organs, fat removed for cleaning), gastrointestinal tract (pharynx, esophagus, stomach and intestines) and carcass characteristics (hot carcass, cold carcass yield, carcass length, leg length, thigh thickness, perimeter of leg, arm length, arm thickness, arm perimeter, front weight, rear weight and conformation). Sample was collected from $\mathrm{HH}$ joint for evaluation of the percentage of bone, muscle and fat and subsequent use of the Longissimus dorsi muscle for evaluation of fat cover thickness, marbling, Longissimus muscle área (LMA), degree of finish, water loss, $\mathrm{pH}$, beef color, fat color and proximate analysis of meat. There was no significant difference $(\mathrm{P}>0.05)$ between treatments for the evaluated parameters for carcass characteristics and non-carcass components. For the parameters of meat quality, there was significant difference $(\mathrm{P}<0.05)$ between treatments only in $\mathrm{pH}$ after 24 hours of slaughter. It is concluded that the use of different corn hybrids in the concentrated diet in feedlot cattle does not influence the carcass characteristics, noncarcass characteristics and meat quality.
\end{abstract}

Key words: Carcass quality, hybrids, ruminant, yield

\footnotetext{
${ }^{1}$ Part of dissertation of the first author - Funded by Araucaria Foundation for Scientific and Technological Development of Paraná and CNPq.

${ }^{2}$ Students of post-graduation in Animal Science Program from State University of Londrina, Londrina-PR, Brazil. E-mail: brunab. sestari@hotmail.com, gianneevans@hotmail.com,massaro@uel.br

${ }^{3}$ Professors of Animal Science Department from State University of Londrina, Londrina - PR. Brazil. ${ }^{3,1}$ Researchers from CNPq. E-mail:mizubuti@uel.br, elar@uel.br; maafbarbosa@uel.br

${ }^{4}$ Professors of Animal Science Department from Federal University of Ceará, Fortaleza, CE, Brazil. ${ }^{4,1}$ Researchers from CNPq. E-mail: elzania@hotmail.com; deiapp@hotmail.com

${ }^{5}$ Researcher of Beef Cattle EMBRAPA, Campo Grande, MS, Brazil. E-mail: gomes_rc@hotmail.com

6 Medicine Veterinary Student at UEL, Londrina, PR, Brazil. CNPq undergraduate scholarship. E-mail: carlarosolem@hotmail.com

* Author for correspondence
} 


\section{Resumo}

O objetivo deste trabalho foi avaliar as características de carcaça, de componentes não carcaça e qualidade da carne de bovinos da raça Nelore terminados em confinamento e alimentados com diferentes híbridos de milho (duro, semi duro e semi dentado) na dieta. Foram utilizados 27 bovinos com peso vivo médio inicial de $350 \pm 24 \mathrm{~kg}$ e idade média de 24 meses, distribuídos em delineamento inteiramente casualizado, em três tratamentos (T), sendo, T1- Dieta com milho duro, T2- Dieta com milho semiduro e T3- Dieta com milho semidentado, com nove repetições por tratamento. As dietas foram isoenergéticas e isoprotéicas, com relação de volumoso: concentrado de 30:70, utilizando-se o bagaço de cana como volumoso e ração concentrada composta de farelo de soja (8\%), milho grão moído (88\%), suplemento mineral e vitamínico (3\%) e uréia (1\%). Estas dietas foram fornecidas aos bovinos duas vezes ao dia $(8 \mathrm{~h}$ e $16 \mathrm{~h}$ ). Os animais foram confinados por um período de 95 dias, compreendendo 14 dias de adaptação e três períodos experimentais de 27 dias. Estes foram pesados em jejum de sólidos de 16 horas no inicio do experimento e ao final de cada período de 27 dias. Ao final do experimento, os animais foram abatidos em frigorífico comercial, mensurando-se os componentes não carcaça (peso do sangue, pés, couro, cabeça, cauda, órgãos, gordura retirada na toailete (pelanca), aparelho gastro-intestinal (faringe, esôfago, estômago e intestinos) e as características de carcaça (rendimento de carcaça quente, rendimento de carcaça fria, comprimento de carcaça, comprimento de perna, espessura de coxão, perímetro de perna, comprimento de braço, espessura de braço perímetro de braço, peso do dianteiro e peso do traseiro e conformação). Foi colhida amostra da secção HH para avaliação da percentagem de osso, músculo e gordura e posterior utilização do músculo Longissimus dorsi para avaliação de espessura de gordura de cobertura, marmoreio, área de olho de lombo, grau de acabamento, perda de água, $\mathrm{pH}$, cor da carne e cor da gordura, bem como, análise centesimal da carne. Não houve diferença significativa $(\mathrm{P}>0,05)$ entre os tratamentos para os diferentes parâmetros avaliados de características de carcaça e de componentes não carcaça. Para os parâmetros de qualidade de carne, observou-se diferença significativa $(\mathrm{P}<0,05)$ entre os tratamentos apenas $\mathrm{pH}$ após 24 horas do abate. Conclui-se que a utilização de diferentes híbridos de milho na dieta concentrada de bovinos de corte em confinamento não influencia as características de carcaça, bem como os componentes não carcaça e as características qualitativas da carne.

Palavras-chave: Híbrido, qualidade de carcaça, rendimento, ruminante

\section{Introduction}

The success of the production system for beef cattle depends on the use of a set of technologies and management practices, exploiting the capacity of the animal to produce meat for greater profitability. It should also consider the social, economic and cultural population aspects, since they influence so decisively on the efficiency of the production process to achieve the expected benefits.

It is known that the consumer market is dynamic and constantly changing, increasing demand for quality of meat. Therefore, as a consequence of global change has arisen the trend of consolidation in conscious consumer to exercise your rights regarding the quality of the product purchased, encouraging specialization in beef cattle to improve management, reduce costs and increase production efficiency.
Thus, researchers have tried to maximize, profitably, the animal production in order to get the carcasses within quality standards, looking for attend a demanding consumer market. The determination of physical and chemical composition of the carcass is critical in this context, since it allows evaluating the effects of different treatments on the animals and determining their impacts on carcass (VAZ; RESTLE, 2003).

Currently the search for increased efficiency in meat production has changed the profile of the Brazilian cattle industry, because the improvement in efficiency means more profitability to the producer. One of the tools used to improve this index is the adequate nutrition, which can reduce the slaughter age, and improve the offtake rate of livestock, increasing the turnover of working capital. However, this practice has a higher cost 
to the producer since the inclusion of concentrates in the diet is essential for a satisfactory result. As food represents about $60-70 \%$ of the total cost of production, both in animals confined or raised extensively, further studies are essential to help maximize the use of food by the animal (MARTINS et al., 2000).

The grains are essential components in the diets of cattle, and corn is one of the most important cereal grains that make up the diet of ruminants, representing an energy source of high quality (CORREA et al., 2002). The corn is present in most diets for ruminants and is essential for providing starch to rumen fermentation. Currently, most of the corn used in feed is a variety with more vitreous endosperm (more hard and dry) for ease of cultivation in the field, since they are more resistant to pests and keeps better in storage.

Knowledge of the effect that different corn varieties can cause the animal production is essential for the development of agriculture. The determination of a corn variety that improves the performance and carcass yield is important for increased profitability, whereas the farmer's profit margin is small and the concentrated food energy, responsible for the fattening of animals, is also one of the items more expensive in the system of meat production.

The determination of the potential use of different corn hybrids involves the evaluation of physical and chemical characteristics of carcass and meat quality, these being correlated with the quality of food.

This study was carried out to evaluate carcass characteristics, non-carcass components and meat quality characteristics of beef cattle in feedlot and fed with different corn hybrids (flint, semi-flint and semi-dent).

\section{Materials and Methods}

The experiment was carried out at the Farm School of Universidade Estadual de Londrina (UEL), located in Londrina - Paraná - Brazil. Laboratory tests were performed at the Laboratory of Food Analysis and Animal Nutrition at the Animal Science Department of UEL.

Twenty-seven Nellore beef cattle averaging 350 $\pm 24 \mathrm{~kg}$ of body weight and 24 months of age were used. The animals were distributed in a completely randomized design with three treatments $(\mathrm{T})$, where, T1 - diet with flint corn (TDFC), T2- diet with semiflint corn (TDSFC) and T3- diet with semi-dent corn (TDSDC). The animals were confined for 95 days, including 14 days for adaptation and three experimental periods of 27 days and were distributed in a way to stay three animals per pen and three pens per treatment (total of 9 pens). The pens were partly covered, provided with a concrete floor, with feeder and drinker. The animals were weighed at the beginning of the experiment and after each period of 27 days, always in a fasting period of 16 hours.

The animals were fed ad libitum twice daily (at 8:00am and 4:00pm) with a isocaloric and isonitrogenous diet, with $30 \%$ of sugar cane bagasse and $70 \%$ concentrate ( $88 \%$ maize, $8 \%$ soybean meal, $3 \%$ mineral and vitamin supplement and $1 \%$ urea) (Table 1 and 2).

The samples were submitted to chemical analysis following the methodology described by Mizubuti et al. (2009). After analysis, the calculations for determining TDN were performed by the formula described by Patterson (2000): TDN $=[88.9-$ $(0.779 \times$ \% ADF)].

The amount of forage and concentrate fed was initially calculated based on $2.5 \%$ of body weight in DM and adjusted daily to achieve $7 \%$ of remains, enabling the animal to the food selection without suffer restriction or forced consumption. The remains were weighed daily at the next day.

At the end of the experiment, the animals were slaughtered in commercial slaughter house located $45 \mathrm{~km}$ from the farm. The slaughter was carried out in accordance with the standards of humanitarian slaughter. Were collected and weighed separately, all the blood, feet, hide, head, tail, organs, fat removed for cleaning and gastrointestinal tract for evaluation of non-carcass components. 
Table 1. Composition of experimental diets.

\begin{tabular}{llccc}
\hline \multirow{2}{*}{ Proportion } & \multirow{2}{*}{ Food } & \multicolumn{3}{c}{ Diets } \\
\cline { 3 - 4 } Forage (30\%) & Sugar cane bagasse & $\mathrm{TDFC}^{1}(\%)$ & $\mathrm{TDSFC}^{2}(\%)$ & TDSDC $^{3}(\%)$ \\
\hline & & 30 & 30 & 30 \\
& Flint corn & 61.6 & ---- & ---- \\
& Semi-flint corn & --- & 61.6 & ---- \\
Concentrate (70\%) & Semi- dent corn & ---- & --- & 61.6 \\
& soybean meal & 5.6 & 5.6 & 5.6 \\
& Supplement & 2.1 & 2.1 & 2.1 \\
& Urea & 0.7 & 0.7 & 0.7 \\
\hline
\end{tabular}

${ }^{1}$ TDFC- Total diet containing flint corn.

${ }^{2}$ TDSFC- Total diet containing semi-flint corn.

${ }^{3}$ TDSDC- Total diet containing semi-dent corn.

${ }^{4}$ Mineral and vitamin supplement, which level of assurance contains at least: Calcium, 120g; Cobalt, 60mg; Copper, 650mg; Sulfur, 20g; Iron, 1.120mg; Phosphorus, 40g; Iodine, 40mg; Magnesium, 94g; Manganese, $520 \mathrm{mg}$; Selenium, 9mg; Sodium, 92g; Zinc 1.960mg; Lasalocid, 1000mg; TDN Dear, 95g; Crude Protein, 50g; Vitamin A, 100,000 IU/kg; Vitamin E, 1000 IU/kg; and a maximum of: Fluorine, 400; NPN - Equivalent protein, $45 \mathrm{~g}$

Source: Elaboration of the authors.

Table 2. Chemical composition of sugar cane bagasse, concentrates and total diet containing flint corn, semi-flint corn and semi-dent corn (dry basis).

\begin{tabular}{lccccccc}
\hline & \multicolumn{7}{c}{ Chemical Composition * } \\
\cline { 2 - 7 } & DM (\%) & MM (\%) & CP (\%) & NDF (\%) & ADF (\%) & EE (\%) & TDN (\%) \\
\hline 1FC & 88.3 & 5.1 & 17.0 & 17.4 & 3.8 & 1.7 & 85.9 \\
2SFC & 88.1 & 5.3 & 17.0 & 18.7 & 4.8 & 1.3 & 85.2 \\
3SDC & 86.7 & 5.7 & 17.0 & 14.2 & 4.7 & 1.7 & 85.2 \\
Sugar cane bagasse & 56.1 & 8.4 & 1.9 & 90.5 & 63.7 & 0.5 & 39.3 \\
4TDFC & 58.83 & 6.65 & 16.16 & 59.28 & 32.68 & 1.5 & 63.43 \\
5TDSFC & 61.91 & 6.24 & 17.25 & 57.38 & 29.16 & 1.78 & 66.18 \\
6TDSDC & 59.69 & 6.55 & 17.11 & 61.08 & 31.67 & 1.32 & 64.22 \\
\hline
\end{tabular}

*DM- Dry matter; MM-Mineral Matter; CP-Crude Protein, NDF- Neutral Detergent Fiber, ADF-Acid Detergent Fiber, EE- Ether Extract, TDN - Total Digestible Nutrients.

${ }^{1} \mathrm{FC}$ : Concentrate containing flint corn.

${ }^{2}$ SFC: Concentrate containing semi-flint corn.

${ }^{3}$ SDC: Concentrate containing semi-dent corn.

${ }^{4}$ TDFC: Total diet containing $30 \%$ of sugar cane bagasse and $70 \%$ of FC

${ }^{5}$ TDSFC: Total diet containing $30 \%$ of sugar cane bagasse and $70 \%$ of SFC

${ }^{6} \mathrm{TDSDC}$ : Total diet containing $30 \%$ of sugar cane bagasse and $70 \%$ of SDC

Source: Elaboration of the authors.

To evaluate the carcass characteristics, it was sawed in half of the sternum and spine, resulting in similar two halves of carcass. These were identified and weighted to evaluate the weight and yield of hot carcass ( $\mathrm{HCW}$ - hot carcass weight in $\mathrm{kg}$ immediately after slaughter). Later, they were cooled for 24 hours at $2^{\circ} \mathrm{C}$, then weighed again to determine weight and cold carcass yield ( $\mathrm{HCY}$ and (CY), which is determined by the ratio of hot carcass weight and / or cold carcass weight and the final body weight. Carcass conformation (CC) was evaluated in a subjective manner according to the method of Muller (1980) where higher values correspond to better conformation. This assessment 
was considered muscle development, aiming to exclude subcutaneous fat.

Were measured: carcass length (CL) in $\mathrm{cm}$, measured with the aid of a measuring tape, between the cranial edge of the pubic bone and the anterior edge of first rib; Leg length (LL), in centimeters measured between the front edge of the pubic bone and the midpoint of bones of the tarsal joint, obtained with a pair of compasses; Thigh thickness (TT) with a pair of compasses, it was found that the distance between the lateral and medial upper portion of the thigh, and thereafter measured the distance between the two ends of the pair of compasses with the aid of a measuring tape.

To obtain the weight of the front was used the right half of carcass, and this was sawn at the fifth rib thereby providing the weight of the front. To obtain the weight of the rear the rest of the right half was weighted.

To evaluate the quality of meat was made a cut between the 9th and 13th ribs by removing the section $\mathrm{HH}$. In this piece was proceeded the evaluation of Longissimus muscle área (LMA).

On the right side of the carcass, was proceeded a cross-section between the 12th and 13th rib, exposing the Longissimus dorsi muscle, which was used to trace its outline on tracing paper and then measuring the area with the aid of a planimeter. A "plastic card" developed by Luchiari Filho (2000), was used.

The fat cover thickness (FCT) was measured in the region of the cut between the 12th and 13th rib, above the Longissimus dorsi muscle and measured with calipers, yielding an average of three points.

The percentages of muscle (MUSC,\%), bone (BONE,\%) and fat (FAT,\%) in the carcass was determined after dissection of HH Section and the percentages corresponding to the 9 th, 10 th and 11 th ribs, were calculated by the regression equations, using the method of Hankins and Howe (1946), mentioned below, thereby obtaining the percentage of muscle $(\mathrm{Ym})$, bone $(\mathrm{Yb})$ and fat (Yf) of the studied carcass: $\mathrm{Ym}=15,56+0,81 \mathrm{M} ; \mathrm{Yb}=4,30+$ $0,61 \mathrm{~B}$ and $\mathrm{Yf}=3,06+0,82 \mathrm{~F}$.

The evaluation of meat Marbling (MAR) was performed subjectively by observing the intramuscular fat of Longissimus dorsi muscle between the 12th and 13th ribs, according to the methodology of Muller (1980).

The muscle color (COLOR) after carcass cooling for 24 hours, was evaluated after cross section of the Longissimus dorsi muscle in the region between the 12 th and 13th ribs by the scale scores (MULLER, 1980).

The $\mathrm{pH}$ of the carcass was measured at 0 and 24 hours after slaughter, at the Longissimus dorsi muscle, through electronic $\mathrm{pH}$ meter with metallic sensor penetration.

The analysis of shear force (tenderness of the meat) was making on samples of the intermediate portion of Longissimus dorsi, using Warner-Bratzler device. Samples $(2.5 \mathrm{~cm}$ thick) were thawed in a refrigerator at $7^{\circ} \mathrm{C}$ for 24 hours and were baked in an electric furnace preheated to $170^{\circ} \mathrm{C}$ until the internal temperature to stay at $70^{\circ} \mathrm{C}$. Removed from the oven, the samples were cooled again in a refrigerator at $7^{\circ} \mathrm{C}$ for 24 hours, according to Whipple et al. (1990). In the central portion of each sample were taken six cylinders of $1.27 \mathrm{~cm}$ in diameter in the direction of muscle fibers. After this, was calculated the average of six measurements of shear force on each sample. After these analyzes, the samples were packaged and frozen for later determination of moisture, ash, crude protein and ether extract (AOAC, 1980).

The data were subjected to analysis of variance by the GLM procedure of SAS (2003), according to the model: 


$$
\mathrm{Y}_{\mathrm{ij}}=\mu+\mathrm{t}_{\mathrm{i}}+\mathrm{e}_{\mathrm{ij}}
$$

$\mathrm{Y}_{\mathrm{ij}}=$ observation of the animal $j$ subjected to the diet $i$;

$\mu=$ general constant;

$\mathrm{t}_{\mathrm{i}}=$ diets effect $i ; i=1 ; \ldots 3$;

$\mathrm{e}_{\mathrm{ij}}=$ random error associated with each observation $\mathrm{Y}_{\mathrm{ij}}$ with mean 0 (zero) and variance $\sigma 2$.

When necessary, means were compared by Tukey test with a significance level of 5\%.

\section{Results and Discussion}

\section{Carcass characteristics}

There was no significant difference $(\mathrm{P}>0.05)$ on carcass characteristics of beef cattle fed with diets containing different corn hybrids (Table 3 ).

The carcass yield was not affected $(\mathrm{P}>0.05)$ by diet, observing average of $55.00 \%$. These results are usually obtained for Nellore cattle (EZEQUIEL et al., 2006a, b; COSTA et al., 2007; IGARASI et al., 2008; ROTTA et al., 2009). Oscillations in the carcass yield are frequent, mainly influenced by the fasting period and in the process of cleaning the carcass in the slaughter.

Table 3. Average of quantitative carcass characteristics and proportion of carcass components (bone, muscle and fat) of feedlot Nellore fed with different corn hybrids.

\begin{tabular}{|c|c|c|c|c|c|}
\hline \multirow{2}{*}{ Variable } & \multicolumn{3}{|c|}{ Diets } & \multirow{2}{*}{$\mathrm{CV}(\%)$} & \multirow{2}{*}{$\mathrm{P}>\mathrm{F}$} \\
\hline & TDFC & TDSFC & TDSDC & & \\
\hline Hot carcass weight (kg) & 244.56 & 250.75 & 242.20 & 6.11 & 0.4904 \\
\hline Cold carcass weight $(\mathrm{kg})$ & 241.92 & 247.90 & 239.61 & 6.12 & 0.5071 \\
\hline Hot carcass yield (\%) & 55.30 & 55.06 & 55.07 & 1.76 & 0.8515 \\
\hline Cold carcass yield (\%) & 54.69 & 54.44 & 55.44 & 3.75 & 0.5753 \\
\hline Carcass length $(\mathrm{cm})$ & 129.61 & 131.62 & 128.60 & 2.60 & 0.1650 \\
\hline Leg length $(\mathrm{cm})$ & 89.33 & 90.25 & 90.70 & 2.74 & 0.4936 \\
\hline Thigh thickness $(\mathrm{cm})$ & 25.33 & 27.06 & 27.65 & 11.31 & 0.2360 \\
\hline Leg perimeter $(\mathrm{cm})$ & 107.66 & 106.25 & 105.20 & 2.68 & 0.1723 \\
\hline Arm length (cm) & 46.61 & 47.00 & 46.40 & 4.03 & 0.8080 \\
\hline Arm thickness (cm) & 11.94 & 11.81 & 12.60 & 11.91 & 0.4701 \\
\hline Arm perimeter $(\mathrm{cm})$ & 56.66 & 57.81 & 56.50 & 3.20 & 0.2789 \\
\hline Finishing grade (Muller) & 1.77 & 1.88 & 1.70 & 45.04 & 0.9063 \\
\hline Weight of the front $(\mathrm{kg})$ & 67.16 & 68.93 & 66.33 & 6.38 & 0.4511 \\
\hline Weight of the rear $(\mathrm{kg})$ & 55.84 & 56.30 & 54.74 & 6.57 & 0.6595 \\
\hline Fat cover thickness (mm) & 2.11 & 3.50 & 2.75 & 48.04 & 0.0940 \\
\hline Rate of marbling (Muller) & 111.11 & 112.50 & 100.0 & 24.85 & 0.5577 \\
\hline $\begin{array}{l}\text { Longissimus muscle área } \\
\left(\mathrm{cm}^{2}\right)\end{array}$ & 68.47 & 65.15 & 69.65 & 13.22 & 0.5776 \\
\hline \multicolumn{6}{|c|}{ Proportion of carcass components (bone, muscle and fat) } \\
\hline Bone $(\%)$ & 17.05 & 17.23 & 17.99 & 9.35 & 0.4217 \\
\hline Muscle (\%) & 57.58 & 56.34 & 55.62 & 6.24 & 0.4949 \\
\hline Fat $(\%)$ & 25.52 & 26.57 & 26.47 & 13.8 & 0.8057 \\
\hline
\end{tabular}

TDFC: Total diet containing $30 \%$ of sugar cane bagasse and $70 \%$ of FC

TDSFC: Total diet containing $30 \%$ of sugar cane bagasse and $70 \%$ of SFC

TDSDC: Total diet containing $30 \%$ of sugar cane bagasse and $70 \%$ of SDC

Source: Elaboration of the authors. 
The carcass length, leg length and thigh thickness, generally has low variation by the diet. The values observed in this experiment are similar to those observed by Prado et al. (2008a, b, c) in cattle in feedlot or pasture. Likewise, Ezequiel et al. (2006a, b) found values similar to leg length and thigh thickness, respectively, 83.3 and 28.9 $\mathrm{cm}$, while Costa et al. (2007) found values of 85.71 and $22.14 \mathrm{~cm}$ for leg length and thigh thickness, respectively, in Nellore cattle.

The determination of the Longissimus muscle área (LMA) is correlated with muscling present in the cattle carcass. A diet isoprotein and isoenergy, as in this case, has little influence on these characteristics. The values obtained in this experiment were similar to those observed in animals finished in feedlot with diets of high energy density (PRADO et al., 2008a, b, c). Ezequiel et al. (2006a, b), working with animals of the same breed and similar slaughter weight, found lower area of $61.9 \mathrm{~cm}^{2}$ and $23.8 \mathrm{~cm}^{2}$ at $100 \mathrm{~kg}$ of carcass. Igarasi et al. (2008), using bovine Red Angus X Nellore, observed greater area $\left(73.98 \mathrm{~cm}^{2}\right)$ than the present study.

The average fat cover thickness (FCT) of animals in the different treatments was $2.78 \mathrm{~mm}$. For storage of the carcass, the minimum requirement of fat cover thickness is $3 \mathrm{~mm}$ (MULLER, 1980). Values below $3.0 \mathrm{~mm}$ determine shortening of muscle fibers and browning the meat modifying their appearance. The low subcutaneous fat thickness can be explained by the following fat deposition in accordance with Pethick, Harper and Oddy (2004), whose deposition of adipose tissue is distributed basically in four different sites: internal fat (abdominal, kidney - inguinal and pelvic), intermuscular (between muscle groups), subcutaneous (coverage) and finally intramuscular fat (marbling).
The marbling rate is an important feature, because it is closely related to sensory characteristics (tenderness, flavor and juiciness) of meat likely to be perceived and appreciated by the consumer (COSTA et al., 2002). However, intramuscular fat is the last to be deposited. According to Di Marco (1998), the fat marbling develops when the animal gains weight at high rates, or when advancing age or body weight, being the last to be deposited and the first to be mobilized when the animal is suffering food restriction. Likewise, Muller and Primo (1986) reported that Bos indicus reduced in amount of meat marbling, compared with pure animals or with bigger participation of Bos taurus genotype.

The percentage of bone, muscle and fat (Table 3) did not differ between diets $(\mathrm{P}>0.05)$, and the values were similar to those observed by Abrahão et al. (2005); Maggioni et al. (2009) e Fugita (2010), in crossbred steers finished in feedlot with similar age to the present work. The proportions of these characteristics tend to change according to the chronological age of the animal because it has bigger bone participation in his carcass when young, and according to their degree of maturity increases there is an increase in muscle growth. Subsequently, when the animal getting older, there is a reduction in the deposition of muscle tissue, and increased in fat deposition, especially when the energy intake is bigger than the need of the animal.

\section{Non-carcass components}

There was no statistical difference $(\mathrm{P}>0.05)$ between variables of non-carcass components (Table 4). This result may be related to the similarity in the observed average for the slaughter weight, hot carcass weight and cold carcass weight (PACHECO et al., $2005 \mathrm{a}, \mathrm{b})$. 
Table 4. Average weight of non-carcass components $(\mathrm{kg})$ of Nellore cattle in a feedlot, fed with different corn hybrids.

\begin{tabular}{lrcrrc}
\hline \multirow{2}{*}{ Variable } & \multicolumn{3}{c}{ Diets } & \multirow{2}{*}{ CV $(\%)$} & \multirow{2}{*}{ P $>\mathrm{F}$} \\
\cline { 2 - 3 } & TDFC & TDSFC & TDSDC & & \\
\hline Blood & 14.46 & 11.28 & 13.90 & 25.27 & 0.1226 \\
Feet & 10.00 & 10.31 & 9.35 & 11.15 & 0.1631 \\
Leather & 40.36 & 40.64 & 40.13 & 9.05 & 0.9617 \\
Head & 11.96 & 12.04 & 11.70 & 5.37 & 0.4999 \\
Tail & 1.16 & 1.18 & 1.20 & 11.06 & 0.8260 \\
Organs & 15.21 & 15.40 & 15.41 & 10.93 & 0.9641 \\
Internal fat & 12.44 & 11.75 & 11.90 & 23.58 & 0.8791 \\
Digestive tract $^{2}$ & 32.64 & 32.11 & 30.76 & 14.04 & 0.6548 \\
\hline
\end{tabular}

${ }^{1}$ Organs (tongue, heart, lung, liver, kidney and spleen).

${ }^{2}$ Digestive tract (mouth, pharynx, esophagus, stomach, intestines)

TDFC: Total diet containing 30\% of sugar cane bagasse and $70 \%$ of FC

TDSFC: Total diet containing $30 \%$ of sugar cane bagasse and $70 \%$ of SFC

TDSDC: Total diet containing $30 \%$ of sugar cane bagasse and $70 \%$ of SDC

Source: Elaboration of the authors.

According to Peron et al. (1993), regardless of feeding level, the weights of the heart and lungs are not affected, indicating that these organs retain their integrity and therefore have priority in the utilization of nutrients.

Animals with larger size of the digestive tract, with the possibility of increased food intake also had higher weights of vital organs, which, according to Owens, Dubeski and Hanson (1993) and Ferrel and Jenkins (1998 a, b), is associated with an increase in metabolic rate for use of nutrients consumed. However, in this experiment there was no significant difference in weight of the liver and digestive tract, probably because the levels of energy, protein and other nutrients of the diet were similar between rations of different treatments, besides the use of one animal breed with the same average weight in the experiment.

The internal fat (cavity and visceral) increases linearly with the addition of concentrate in the diet, and this effect can be attributed to higher energy consumption (FERREIRA, 1997), and the highest proportion of internal fat leads, in practice, higher energy requirements for maintenance, due to higher metabolic activity of adipose tissue (SOLIS et al., 1988; OWENS et al., 1995). Considering that the internal fat is not used for human consumption, food would be wasted. In this case again, there was no significant differences between treatments, this can be explained by the fact that the feed of the various diets had the same amount of energy.

The weight of the head, tail, feet, blood and digestive tract, are usually constant and the change is insignificant in relation to animals of the same weight and same breed. This can be confirmed with the data obtained in this experiment where, the weights of head, feet and tail, showed no statistical difference between the animals of studied diets.

\section{Qualitative characteristics of meat}

To the qualitative characteristics of meat (Table 5) it was observed that there was significant differences $(\mathrm{P}<0.05)$ only in variable $\mathrm{pH} 24$ hours after slaughter, with values ranging from 6.16 to 6.54 .

The $\mathrm{pH}$ is one of the most important features related to the quality of meat, because it interferes directly on the capacity of water retention, color and muscle structure (SILVEIRA, 1997). In the living muscle the $\mathrm{pH}$ is around 7 , and in fresh meat the ideal $\mathrm{pH}$ should be between 5.6 and 5.8 
(LUCHIARI FILHO, 2000). In general, the $\mathrm{pH}$ of the meat decreases linearly with time $(y=6.18$ $0.019 x$ ), about 0.019 units per hour. With the death and, consequently, with the failure of blood, oxygen supply and nervous control fail to reach the muscle, making the muscle to use the anaerobic route to obtain energy for the contractile process, in this process there is transformation of glycogen into glucose, and the glucose is anaerobic what generate lactate causing a decrease in $\mathrm{pH}$ (ALVES; TONISSI; GOES, 2005; GÓES et al., 2005).

However, the short or long stress in the preslaughter management can lead to increased pós- mortem glycolysis causing a breakdown in the process of the fall of $\mathrm{pH}$. Chronic and prolonged stress before slaughter can lead to depletion of muscle glycogen and low lactic acid production in anaerobic glycolysis. Thus, the $\mathrm{pH}$ that should fall to approximately 5.6, stay stabilized at values above 6.0 characterizing DFD meat (dark, firm and dry), in other words, the meat shows dark color, firm texture and high capacity of water retention. The DFD meat is rejected for fresh consumption. For industrialization, the DFD meat is not suitable for the preparation of raw products, because the $\mathrm{pH}$ around 6.0 favors microbial contamination, reducing the shelf life (FAUCITANO, 2000).

Table 5. Meat quality of Nellore cattle in a feedlot, fed with different corn hybrids.

\begin{tabular}{lccccc}
\hline \multirow{2}{*}{ Variable } & \multicolumn{3}{c}{ Diets } & \multicolumn{2}{c}{ CV } \\
& TDFC & TDSFC & TDSDC & \multirow{2}{*}{ P $>$ F } \\
\cline { 2 - 4 } Loss of water by pressure (\%) & 24.02 & 21.72 & 19.66 & 24.77 & 0.2135 \\
Loss of water by drip (\%) & 1.68 & 1.68 & 1.75 & 37.16 & 0.9664 \\
pH at slaughter & 6.82 & 6.93 & 6.62 & 5.33 & 0.1760 \\
pH 24 hours after slaughter & $6.19 \mathrm{~b}$ & $6.54 \mathrm{a}$ & $6.16 \mathrm{~b}$ & 5.14 & 0.0196 \\
Shear force (kgf) & 5.47 & 5.94 & 6.38 & 26.82 & 0.4725 \\
Meat color (L) & 36.85 & 37.14 & 36.23 & 3.99 & 0.4089 \\
Meat color (a) & 13.93 & 14.18 & 15.35 & 12.15 & 0.8761 \\
Meat color (b) & 7.83 & 8.17 & 7.91 & 6.66 & 0.4176 \\
Fat color (L) & 72.75 & 72.96 & 71.56 & 5.11 & 0.6955 \\
Fat color (a) & -0.03 & -0.28 & -0.32 & -961.95 & 0.9522 \\
Fat color (b) & 10.77 & 10.16 & 8.47 & 34.10 & 0.3038 \\
\hline & Proximate composition of meat (\%) & & \\
\hline Dry matter & 25.58 & 25.61 & 25.73 & 2.55 & 0.8800 \\
Mineral matter & 1.03 & 1.04 & 1.03 & 4.20 & 0.8301 \\
Ether extract & 1.45 & 1.65 & 1.38 & 34.70 & 0.5403 \\
Protein & 21.44 & 21.36 & 21.88 & 2.80 & 0.3201 \\
\hline
\end{tabular}

TDFC: Total diet containing $30 \%$ of sugar cane bagasse and $70 \%$ of FC

TDSFC: Total diet containing $30 \%$ of sugar cane bagasse and $70 \%$ of SFC

TDSDC: Total diet containing $30 \%$ of sugar cane bagasse and $70 \%$ of SDC

Source: Elaboration of the authors.

According to Normative Instruction $\mathrm{N}^{\circ} 44$ (BRASIL, 2007), the marketing of beef is only permitted provided that the carcass has gone through the process of maturation sanitary in temperature above $+2{ }^{\circ} \mathrm{C}$ for a minimum period of 24 hours after slaughter, and the $\mathrm{pH}$ has not reached a value exceeding 6.0, occurred in the center of the Longissimus dorsi muscle. At the end of this process, the carcass must attain the temperature $\leq$ $5^{\circ} \mathrm{C}$ on the surface (axillary and cervical) within $2 \mathrm{~cm}$ of the muscle, and $6.5^{\circ} \mathrm{C}$ in the courts with greater muscle mass, within 24 hours of cooling and $\mathrm{pH}$ up to 6.4. 
In this experiment can be seen that the animals fed with diet containing semi-flint corn, had meat with $\mathrm{pH}$ of 6.54 which according to Normative Instruction $\mathrm{N}^{\circ} 44$ (BRASIL, 2007), are not recommended for commercialization. This fact can be explained by the stress caused to the animals before slaughter which resulted in DFD meat.

Although the final $\mathrm{pH}$ of the meat has been raised, it had no influence on the meat color and the water retention capacity of the meat in the different diets.

Color is the first sensory characteristic evaluated by the consumer, being associated with the quality and degree of freshness of the meat (MILLER, 2003). In general, the color has a negative correlation with the values of $\mathrm{pH}$, when the meat $\mathrm{pH}$ is higher, the $\mathrm{L} *$ value is lower, in other words, the meat is presented darker. The DFD meat is darker because the accumulation of intracellular water favors the absorption of light.

The meat of semi-flint corn diet had higher $\mathrm{pH}$, although not significant, showed a higher numerical value of L*. Muchenje et al. (2009) reported that, in bovines, the mean of brightness ( $\mathrm{L} *$ ) ranging from 33.2 to 41.0 ; the mean of redness $\left(a^{*}\right)$ from 11.1 to 23.6 and the mean yellow $\left(b^{*}\right)$, from 6.1 to 11.3 . In this study, the mean of $\mathrm{L}^{*}$ and $\mathrm{a}^{*}$ have remained within the range described by Muchenje et al. (2009) and in the range considered normal for beef color described by Abularach, Rocha and Felício (1998).

The values found in the composition of meat (dry matter, ash, crude protein and ether extract) of Longissimus dorsi muscle (Table 5), it was found that were consistent with values reported by Kazama et al. (2008), Rotta et al. (2009) and Zawadzki (2009). In general, the content of ash and crude protein of Longissimus dorsi have low variation for the change in animal diet. On the other hand, although not significant, it was observed that the percentage of lipids in Longissimus was low for feedlot animals with high energy intake (71.6\% TDN), but is close to the results obtained by Zawadzki (2009), who worked with young animals (24 months), the zebu breed (Nellore).

\section{Conclusion}

The use of different corn hybrids in the diet of feedlot beef cattle does not influence the characteristics of carcass and non-carcass components and meat quality.

Cattle fed with ration containing semi-flint corn and subjected to stress pre-slaughter, may have losses in meat quality, with an increase in pH 24 after slaughtering.

\section{Acknowledgements}

To Araucária Foundation for provide the financial resources to perform this research and CNPq for granting the productivity scholarship for the researchers Mizubuti, Ribeiro and Pereira.

\section{References}

ABRAHÃO, J. J. S.; PRADO, I. N.; PEROTTO, D.; MOLETTA, J. L. Características de carcaças e da carne de tourinhos submetidos a dietas com diferentes níveis de substituição do milho por resíduo úmido da extração da fécula de mandioca. Revista Brasileira de Zootecnia, Viçosa, MG, v. 34, n. 5, p. 1640-1650, 2005.

ABULARACH, M. L.; ROCHA, C. E.; FELÍCIO, P. E. Características de qualidade do contra-filé (m. L. dorsi) de touros jovens da raça Nelore. Ciência e Tecnologia de Alimentos, Campinas, v. 18, n. 2, p. 205-210, 1998.

ALVES, D. D.; TONISSI, R. H.; GOES, B. Maciez da carne bovina. Ciência Animal Brasileira, Goiânia, v. 6, n. 3, p. 135-149, 2005.

ASSOCIATION OF OFFICIAL ANALYTICAL CHEMISTS - AOAC. Official methods of analysis. 14. ed. Washington, D.C., 1984. 1141 p.

BRASIL. MINISTÉRIO DA AGRICULTURA, PECUÁRIA E ABASTECIMENTO. Instrução Normativa $\mathrm{n}^{\circ} 44$, de 2 de outubro de 2007. Diário Oficial [da] União, no 191, de 3 de outubro de 2007, seção 1, p. 2-1,. 2007.

CORREA, C. E. S.; SHAVER, R. D.; PEREIRA, M. N.; LAVER, J. G.; KOHN, K. Relationship between corn vitreousness and ruminal in situ starch degradability. Journal of Dairy Science, Madison, v. 85, n. 11, p. 308312, 2002. 
COSTA, D.; ABREU, J. B. R.; MOURÃO, R. C.; SILVA, J. C. G.; RODRIGUES, V. C.; SOUZA, J. C. D.; MARQUES, R. A. F. S. Características de carcaça de novilhos inteiros Nelore x Holândes. Ciência Animal Brasileira, Goiânia, v. 8, n. 4, p. 687-696, 2007.

COSTA, M. A. L.; VALADARES FILHO, S. C.; PAULINO, M. F. Desempenho produtivo de novilhos zebu alimentados com dietas contendo diferentes níveis de concentrado. In: REUNIÃO ANUAL DA SOCIEDADE BRASILEIRA DE ZOOTECNIA, 39., 2002, Recife. Anais... Recife: RBZ, 2002. CD-ROM.

DI MARCO, O. N. Crescimento de vacunos para carne. Mar Del Plata: Balcarce, 1998. 246.

EZEQUIEL, J. M. B.; GALATI, R. L.; MENDES, A. R.; FATURI, C. Desempenho e características de carcaça de bovinos Nelore em confinamento alimentados com bagaço de cana-de-açúcar e diferentes fontes energéticas: Revista Brasileira de Zootecnia, Viçosa, MG, v. 35, n. 5, p. 2050-2057, 2006b.

EZEQUIEL, J. M. B.; SILVA, O. G. C.; GALATI, R. L.; WATANABE, P. H.; BIAGIOLI, B.; FATURI, C. Desempenho de novilhos nelore alimentados com casca de soja ou farelo de gérmen de e milho em substituição parcial ao milho moído. Revista Brasileira de Zootecnia, Viçosa, MG, v. 35, n. 2, p. 569-575, 2006 a.

FAUCITANO, L. Efeitos do manuseio pré-abate sobre o bem-estar e sua influência sobre a qualidade da carne. In: CONFERÊNCIA VIRTUAL INTERNACIONAL SOBRE QUALIDADE DE CARNE SUÍNA, 1., 2000, Concórdia. Anais... Concórdia: [s.n], p. 21.

FERREIRA, M. A. Desempenho, exigências nutricionais e eficiência de utilização da energia metabolizável para ganho de peso de bovinos F1 Simental x Nelore. 1997. Tese (Doutorado em Zootecnia) - Universidade Federal de Viçosa, Viçosa, MG.

FERREL, C. L.; JENKINS, T. G. Body composition and energy utilization by steers of diverse genotypes fed a high concentrate diet during the finishing period: II. Angus, Boran, Brahman, Hereford, and Tuli Sires. Journal of Animal Science, Champaign, v. 76, p. 647657, 1998b.

Body composition and energy utilization by steers of diverse genotypes fed a high-concentrate diet during the finishing period: I. Angus, Belgian Blue, Hereford, and Piemontese Sires. Journal of Animal Science, Champaign, v. 76, p. 637-646, 1998a.

FUGITA, C. A. Silagem de milho com e sem inoculante enzimo-bacteriano sobre desempenho, características de carcaça e qualidade de carne de bovinos mestiços terminados em confinamento. 2010. Dissertação (Mestrado em Zootecnia) - Universidade Estadual de Maringá, Maringá.
GÓES, R. H. T. B.; MANCIO, A. B.; LANA, R. P.; LEÃO, M. I.; ALVES, D. D.; SILVA, A. T. S. Recria de novilhos mestiços em pastagem de Brachiaria brizantha, com diferentes níveis de suplementação, na região Amazônica. Consumo e parâmetros ruminais. Revista Brasileira de Zootecnia, Viçosa, MG, v. 34, n. 5, p. 17301739, 2005.

HANKINS, O. G.; HOWE, P. E. Estimation of the composition of beef carcasses and cuts. Washington: United Sates Department of Agriculture, 1946. 19 p. (Technical Bulletin - USDA, 926).

IGARASI, M. S.; ARRIGONI, M. B.; HADLICH, J. C.; SILVEIRA, A. C.; MARTINS, C. L.; OLIVEIRA, H. N. Características de carcaça e parâmetros de qualidade de carne de bovinos jovens alimentados com grãos úmidos de milho ou de sorgo. Revista Brasileira de Zootecnia, Viçosa, MG, v. 37, n. 3, p. 520-528. 2008.

KAZAMA, R.; ZEOULA, L. M.; PRADO, I. N.; SILVA, D. C.; DUCATTI, T.; MATSUSHITA, M. Quantitative and qualitative carcass characteristics of heifers fed different energy sources on a cottonseed hulls and soybean hulls based diet. Brazilian Journal of Animal Science, Viçosa, MG, v. 37, n. 2, p. 350-357, 2008.

LUCHIARI FILHO, A. Pecuária da carne bovina. São Paulo: Editora São Paulo: 2000. 134 p.

MAGGIONI, D.; MARQUES, J. A.; PEROTTO, D.; ROTTA, P. P.; DUCATTI, T.; MATSUSHITA, M.; SILVA, R. S.; PRADO, I. N. Bermuda Grass hay or sorghum silage with or without yeast addition on performance and carcass characteristics of crossbred young bulls finished in feedlot. Asian Australasian Journal of Animal Science, Seoul, v. 22, n. 2, p. 206-215, 2009.

MARTINS, A. S.; PRADO, I. N.; ZEOULA, L. M.; BRANCO, A. F.; NASCIMENTO, W. G. Digestibilidade aparente de dietas contendo milho ou casca de mandioca como fonte energética e farelo de algodão ou levedura como fonte protéica em novilhas. Revista Brasileira de Zootecnia, Viçosa, MG, v. 29, n. 1, p. 269-277, 2000.

MILLER, R. Assessing consumer preferences and attitudes toward meat products. Brazillian Journal of Food Technology, Campinas, v. 6, p. 67-80, 2003. Special Issue.

MIZUBUTI, I. Y.; PINTO, A. P.; PEREIRA, E. S.; RAMOS, B. M. O. Métodos laboratoriais de avaliação de alimentos para animais. Londrina: EDUEL. 2009. $228 \mathrm{p}$.

MUCHENJE, V.; DZAMAC, B. K.; CHIMONYOA, M.; STRYDOM, P. E.; HUGO, A.; RAATS, J. G. Some biochemical aspects pertaining to beef eating quality and consumer health: a review. Food Chemistry, Netherlands, v. 112, n. 2, p. 279-289, 2009. 
MULLER, L. Normas para avaliação de carcaças $e$ concurso de carcaça de novilhos. Santa Maria: UFSM, $980.31 \mathrm{p}$.

MULLER, L.; PRIMO, A. T. Influência do regime alimentar no crescimento e terminação de bovinos e na qualidade da carcaça. Pesquisa Agropecuária Brasileira, Brasília, DF, v. 21, n. 4, p. 445-452, 1986.

OWENS, F. N.; GILL, D. R.; SECRIST, D. S.; COLEMAN, S. W. Review of some aspects of growth and development of feedlot cattle. Journal of Animal Science, Champaign, v. 73, n. 10, p. 3152-3172, 1995.

OWENS, F. N.; DUBESKI, P.; HANSON, C. F. Factors that alter the growth and development of ruminants. Journal of Animal Science, Champaign, v. 71, n. 11, p. 3138-3150, 1993.

PACHECO, P. S.; RESTLE, J.; SILVA, J. H. S.; ARBOITTE, M. Z.; FILHO, D. C. A.; FREITAS, A. F.; ROSA, J. R. P.; PÁDUA, J. T. Características das partes do corpo nãointegrantes da carcaça de novilhos jovens e superjovens de diferentes grupos genéticos. Revista Brasileira de Zootecnia, Viçosa, MG, v. 34, n. 5, p. 16781690, 2005b.

PACHECO, P. S.; SILVA, J. H. S.; RESTLE, J.; ARBOITTE, M. Z.; BRONDANI, I. L.; FILHO, D. C. A.; FREITAS, A. K. Características da carcaça de novilhos jovens e superjovens de diferentes grupos genéticos. Revista Brasileira de Zootecnia, Viçosa, MG, v. 34, n. 5, p. 1666-1677, 2005a.

PATTERSON, T.; KLOPFENSTEIN, T. J.; MILTON, T.; BRINK, D. R. Evaluation of the 1996 beef cattle NRC model predictions of intake and gain for calves fed low or medium energy density diets. Nebraska Beef Report, p. 26-29, 2000. MP 73-A.

PERON, A. J.; FONTES, C. A. A.; LANA, R. P.; QUEIROZ, A. C.; SILVA, D. J.; FREITAS, J. A. F. Predição da composição corporal e da carcaça de bovinos através de métodos indiretos. Revista da Sociedade Brasileira de Zootecnia, Viçosa, MG, v. 22, n. 2, p. $227-$ 237, 1993.

PETHICK, D. W.; HARPER, G. S.; ODDY, V. H. Growth, development and nutritional manipulation of marbling in cattle: A review. Australian Journal of Experimental Agriculture, Collingwood, v. 44, n. 7, p. 705-715, 2004.

PRADO, I. N.; ITO, R. H.; PRADO, J. M.; PRADO, I. M.; ROTTA, P. P.; MATSUSHITA, M.; VISENTAINER, J. V.; SILVA, R. R. The influence of dietary soybean and linseed on the chemical composition and fatty acid profile of the longissimus muscle of feedlot-finished bulls. Journal of Animal Feed Science, Jablonna, v. 17, n. 3, p. 307-317, 2008a.
PRADO, I. N.; PRADO, R. M.; ROTTA, P. P.; VISANTAINER, J. V.; MOLETTA, J. L.; PEROTTO, D. Carcass characteristics and chemical composition of the longissimus muscle of crossbred bulls (Bos Taurus indicus vs Bos taurus taurus) finished in feedlot. Journal Animal Feed Science, Jablonna, v. 17, n. 3, p. 295-306. 2008 b.

PRADO, I. N.; ROTTA, P. P.; PRADO, R. M.; VISENTAINER, J. V.; MOLETTA, J. L.; PEROTTO, D. Carcass characteristics and chemical composition of the Longissimus muscle of Purunã and $1 / 2$ Purunãx $1 / 2$ Canchin bulls. Asian Australasian Journal of Animal Science, Seoul, v. 21, n. 9, p. 1296-1302, 2008c.

ROTTA, P.P.; PRADO, I. N.; PRADO, R. M.; MOLETTA, J. L.; SILVA, R. R.; PEROTTO, D. Carcass characteristics and chemical composition of the Longissimus muscle of Nellore, Caracu and Holstein-friesian bulls finished in feedlot. Asian- Australasian Journal Animal Science, Seoul, v. 22, n. 4, p. 598-604, 2009.

SILVEIRA, E. T. F. Técnicas de abate e seus efeitos na qualidade da carne suina. 1997. Tese (Doutorado em Tecnologia de Alimentos) - Faculdade de Engenharia de Alimentos. Universidade Estadual de Campinas, Campinas.

SOLIS, J. C.; BYERS, F. M.; SCHELLING, G. T.; LONG, C. R.; GREENE, L. W. Maintenance requirements and energetics efficiency of cows of different breeds types. Journal of Animal Science, Champaign, v. 56, n. 5, p. 1241-1251, 1988.

SAS Institute. Statistical analysis system for windows ${ }^{\circledR}$. Version 9.1.3. Cary, NC, USA, 2003.

VAZ, F. N.; RESTLE, J. Ganho de peso antes e após os sete meses no desenvolvimento e nas características de carcaça e carne de novilhos Charolês abatidos aos dois anos. Revista Brasileira de Zootecnia, Viçosa, MG, v. 32, n. 3, p. 699-708, 2003.

WHIPPLE, G.; KOOHMARAIE, M.; DIKEMAN, M. E.; CROUSE, J. D.; HUNT, M. C.; KLEMM, R. D. Evaluation of attributes that affect Longissimus muscle tenderness in Bos taurus and Bos indicus cattle. Journal of Animal Science, Champaign, v. 68, n. 9, p. 2716-2728, 1990.

ZAWADZKI, F. Monoensina sódica ou extrato de própolis na dieta de bovinos nelore terminados em confinamento: desempenho, características da carcaça e composição do músculo Longissimus. 2009. Dissertação (Mestrado em Zootecnia) - Universidade Estadual de Maringá, Maringá. 